\title{
Physico-chemical analysis of Sugar mill Effluent and their Impact on Changes of Growth of Wheat (Triticum aestivum) and Maize (Zea mays L.)
}

\author{
Saurabh Saini ${ }^{1}$ and Shailja Pant ${ }^{2}$ \\ Department of Microbiology, Dolphin (P.G) Institute of Biomedical and Natural Science, Manduwala, \\ Dehradun.India
}

\begin{abstract}
The physico-chemical characteristics of the content in the effluents from sugar mill of Haridwar district have been explored and its impact on the germination and growth patterns of wheat and maize has been studied. Physico-chemical characteristics included color, odour, temperature, $\mathrm{pH}$, electrical conductivity, total hardness, BOD,COD, TSS, TDS, $K, P, N a$, Ammonia and Chloride concentration. The seeds of Wheat and Maize were incubated with concentration of effluent dilution ranging from control, 0\%, 25\%, 50\%, 75\% and $100 \%$. It was found that concentration of $25 \%$ and $50 \%$ has stimulatory effects on germination rate and further increase in concentration (beyond 50\%) showed inhibitory effects on germination percentage and initial growth of Wheat (Triticum aestivum) and Maize (Zea mays L.).
\end{abstract}

Keywords: Effluent, Haridwar, Physico-chemical parameters, Seed Germination.

\section{Introduction}

Sugar industry is one of the most important agro-based industries in India and has significantly contributed to countries economy [6,25, and 26]. As India is the largest producer of sugarcane in the world with 550 sugarmills and 220 million tons cane per year and total sugar production 13.5 million tons per year. Sugar production processing require huge water for a number of steps and released almost equal quantity of effluent which contain toxic material $[8,10]$.The recent studies have indicated that the effluent discharge from sugarmill consist of a number of organic and heavy metal pollutant in dissolved or suspended form that can bring about changes in the physical, chemical and physiological sphere of the biota [8,21]. The effluents of industries has ultimate disposal in agriculture field, which can alter the soil properties and crop yielding [4, 6, 22\&26].

Sugar industries effluents are commonly used for irrigation, so it is significant to determine the response of industrial effluents on crops. Seed germination studies have been made on many crops such as rice, wheat, pine, green-gram, Sorghum, Moong, Raphanus \& Sugarcane[6, 25,26].The present paper deals with the estimation of Physico-chemical parameters of sugarmill effluent collected from sugarmill located at district Haridwar. The study was conducted during a period from Nov.2012 to Jan 2013 and an attempt has been made to study the physico-chemical properties of sugar factory effluent and determine the effects of different dilution $(0-100 \%)$ on seed germination of Wheat (Triticum aestivum) and Maize (Zea mays).

\subsection{Seed materials}

\section{Materials And Methods}

Seeds of Wheat (Triticum aestivum) and Maize (Zea mays L.) were purchased from market; uniformity was maintained regarding size, color and weight for better interpretation.

\subsection{Collection of effluent from the sugarmill}

The effluent samples were collected in a pre- cleaned, plastic container from the point of disposal from a sugarmill located in Haridwar district, Uttarakhand, India. The collected effluent was stored at $4^{\circ} \mathrm{C}$ to maintain its original characteristics [27].

\subsection{Physico-chemical characterization of the effluent}

Physico-chemical parameters like Color, Odour, Temperature, and $\mathrm{pH}$ were determined immediately at the site of collection. Electric conductivity (EC), Total Hardness (TH), Biological oxygen demand (BOD), Total solids (TS), Total suspended solids (TSS), Total dissolve solids (TDS), Phosphate, Potassium and Sodium were determined in the laboratory as per standard protocol [1].

\subsection{Effect on seed Germination}

The different concentration of the effluents, $25 \%, 50 \%, 75 \%$ and $100 \%$ were prepared by diluting the effluent with distilled water. Petri plate method was used for germination experiment.

The seed of Wheat (Triticum aestivum) and Maize (Zea mays L.) were surface sterilized with $0.1 \% \mathrm{w} / \mathrm{v}$ $\mathrm{HgCl}_{2}$ solution for $2 \mathrm{~min}$ and then washed three times with sterile distilled water. Seeds were spread on sterilized Petri dish lined with blotting paper and then irrigated with $5 \mathrm{ml}$ of the different concentration of sugar industry 
effluent. Each treatment consisted of three plates with 10 seeds /plate and was examined regularly for germination of seeds at an interval of 24 hours [14, 17 \& 25].

The germination of seed was assessed in percentage and the root and shoot length of the plants recorded every $24 \mathrm{~h}$ for 10 days. The fresh and total dry masses of maize and wheat were determined after 10 days of the experiment. The plants were washed thoroughly with distilled water and were dried for $2 \mathrm{~h}$ under natural conditions at an open roof. The fresh weights were taken and then the plants packed in paper envelopes and oven dried for $36 \mathrm{~h}$ at $70^{\circ} \mathrm{C}$. The dry weight of each plant was also recorded [2].

\section{Result And Discussion}

Physico-chemical characters of sugar mill effluent are presented in Table-1. The effluent released from the main outlet of sugar mill was brown in color and had a smell of decaying molasses. Its brown color could be due to the presence of melanoidin, the product of sugar amine condensation and unpleasant smell due the presence of indole and other sulphur compound [19].The $\mathrm{pH}$ was acidic in nature because of the use of phosphoric acid and sulphuric acid during clarification of sugarcane juice [2, 12].It contained fewer amounts of suspended solids $(132 \mathrm{mg} / \mathrm{ml})$ and total dissolved solids $(1453 \mathrm{mg} / \mathrm{ml})$. The Biological oxygen demand (BOD) and Chemical oxygen Demand (COD) of the effluent were found $90 \mathrm{mg} / \mathrm{ml}$ and $317 \mathrm{mg} / \mathrm{ml}$, respectively. Effluent also contained other elements such as Chloride $(60 \mathrm{mg} / \mathrm{ml})$, Phosphate $(1.2 \mathrm{mg} / \mathrm{ml})$, Ammonia $(4.4 \mathrm{mg} / \mathrm{ml})$, potassium $(16.0 \mathrm{mg} / \mathrm{ml})$ and sodium as $\mathrm{NaOH}(794.8 \mathrm{mg} / \mathrm{ml})$. The presence of considerable high value of BOD, COD, TDS, and Sodium, whereas, Temperature, TSS, Phosphate, Chloride and Total hardness were below permissible limits noticed in the effluent. This is in conformity with the earlier finding of [2, 7, 20. 23 \& 27].

Variation in germination percentage, root length and shoot length with variation in concentration of sugar industry effluent utilized for treatment of seeds clearly revealed that effluent exhibits profound effect on the above mentioned physiological parameters. Observation made from the experiments conducted indicate that with gradual increase in concentration of effluent (50-100\%), a gradual decrease in both germination rate as well as in root and shoot length was observed. Among various concentrations of effluent which were utilized during the study $25 \%$ concentration of effluent was found to be most effective in increasing the germination rate and other parameters in wheat plant (Fig.1\&2) and in maize plants (Fig.3-5). The results are in concordance with the work done by $[7,14,25 \& 28]$, which also indicated that lower concentration of effluent favored the plant growth as well as increasing chemical content.

Germination rate of $90 \%$ was observed in wheat seeds treated with $25 \%$ effluent concentration with an average root length, shoot length, fresh weight and dry weight of $5.4 \mathrm{~cm}, 6 \mathrm{~cm}, 0.154 \mathrm{~g}$ and $0.045 \mathrm{~g}$ respectively(Fig.6,7\&8). Similarly germination rate in maize seed was also maximum (96\%) in seed treated with effluent of concentration $25 \%$, having average root length, shoot length, fresh and dry weight of $10.2 \mathrm{~cm}, 6.4 \mathrm{~cm}$, $0.799 \mathrm{~g}$ and 0.159 grespectively(Fig.9,10\&11). The same effects on germination percentage of maize are also reported in literature $[9,15,16 \& 18]$.

However, germination percentage decrease to $70-40 \%$ in wheat and $80 \%$ in maize when seed were treated with higher concentration of effluent (75-100\%) [18]. A similar decrease was also observed in root and shoot length on higher concentration of effluent. (Table-2 \& 3).The growth and germination percentage of seed inhibited at higher concentration of effluent may be due to osmotic pressure of high dose, which make imbibitions more difficult and reduce oxygen uptake by seedling [2, 3\&11]. While diluting the effluent enhance the plant activities by providing required amount of nutrient present [27].The effect of different effluent concentration varies from crop to crop because each plant has its own tolerance capability [13, 17\&23].

\section{Figures and Tables}

Table.1-Physico-chemical Parameters of Effluent.

\begin{tabular}{|c|c|c|c|}
\hline S.no & Parameters & Effluent & IS \\
\hline 1. & Colour & Brown & Colourless \\
\hline 2 & Odour & Decaying Smell & 40 \\
\hline 3 & Temperature $\left({ }^{\circ} \mathrm{C}\right)$ & 24 & 200 \\
\hline 4 & Total Suspended Solid & 132 & 1000.0 \\
\hline 5 & Total Dissolved Solid & 1453 & 600.0 \\
\hline 6 & Total Hardness & 52 & $6.5-8.5$ \\
\hline 7 & pH & 6.4 & 300.0 \\
\hline 8 & Electric conductivity & 2.20 & 30.0 \\
\hline 9 & BOD & 90 & 250 \\
\hline 10 & COD & 317 & 10.0 \\
\hline 11 & Phosphates (as P) & 1.2 & - \\
\hline 12 & Potassium & 16.0 & 200 \\
\hline 13 & Na (as NaOH) & 794.8 & - \\
\hline 14 & Ammonia & 4.4 & 600 \\
\hline 15 & Chloride & 60 & \\
\hline
\end{tabular}

All values are expressed in $\mathrm{mg} / \mathrm{L}$, except Temperature, Color, Odour $\mathrm{pH}$ and EC 
Table-2: Effect of effluent on various growth parameters of Wheat (Triticum aestivum)

\begin{tabular}{|c|c|c|c|c|c|c|}
\hline S.No & Dilution \% & $\begin{array}{c}\text { Rate of Germination } \\
(\%)\end{array}$ & $\begin{array}{c}\text { Length of } \\
\text { root(cm) }\end{array}$ & $\begin{array}{c}\text { Length of } \\
\text { shoot(cm) }\end{array}$ & $\begin{array}{c}\text { Fresh } \\
\text { weight }(\mathrm{g})\end{array}$ & $\begin{array}{c}\text { Dry } \\
\text { weight(g) }\end{array}$ \\
\hline 1 & Control(0) & 80 & 5.3 & 5.8 & 0.143 & 0.044 \\
\hline 2 & 25 & 90 & 5.4 & 6.0 & 0.154 & 0.045 \\
\hline 3 & 50 & 80 & 4.0 & 4.0 & 0.128 & 0.039 \\
\hline 4 & 75 & 70 & 4.0 & 3.6 & 0.139 & 0.042 \\
\hline 5 & 100 & 40 & 3.3 & 3.4 & 0.130 & 0.040 \\
\hline
\end{tabular}

Table-3: Effect of effluent on various growth parameters of Maize (Zea mays)

\begin{tabular}{|c|c|c|c|c|c|c|}
\hline S.No & $\begin{array}{c}\text { Dilution } \\
\%\end{array}$ & $\begin{array}{c}\text { Rate of Germination } \\
(\%)\end{array}$ & $\begin{array}{c}\text { Length of Root } \\
(\mathrm{cm})\end{array}$ & $\begin{array}{c}\text { Length of Shoot } \\
(\mathrm{cm})\end{array}$ & $\begin{array}{c}\text { Fresh } \\
\text { weight }(\mathrm{g}) \\
\text { weight }(\mathrm{g})\end{array}$ \\
\hline 1 & Control(0) & 93 & 7.5 & 5.6 & 0.616 \\
\hline 2 & 25 & 96 & 10.2 & 6.4 & 0.799 & 0.123 \\
\hline 3 & 50 & 90 & 8.3 & 4.8 & 0.734 & 0.146 \\
\hline 4 & 75 & 90 & 3.5 & 2.0 & 0.140 \\
\hline 5 & 100 & 80 & & & 0.122 \\
\hline
\end{tabular}

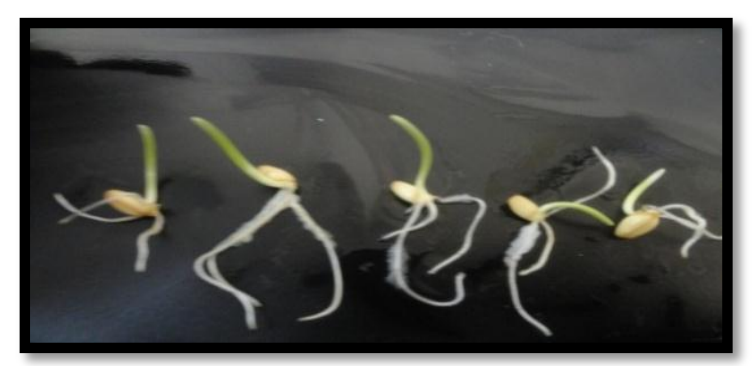

Figure.1 Germination pattern of Wheat plant

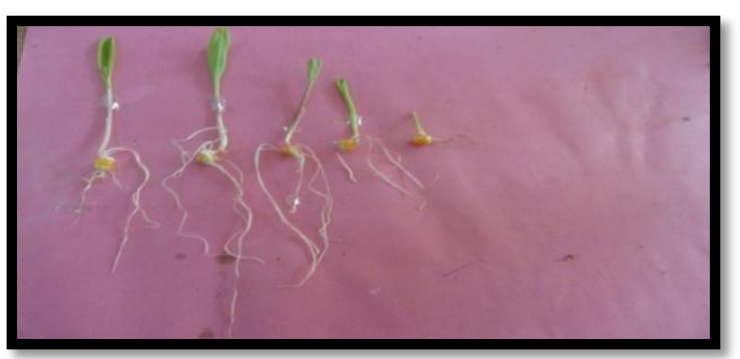

Figure.3 Growth pattern of maize plant.

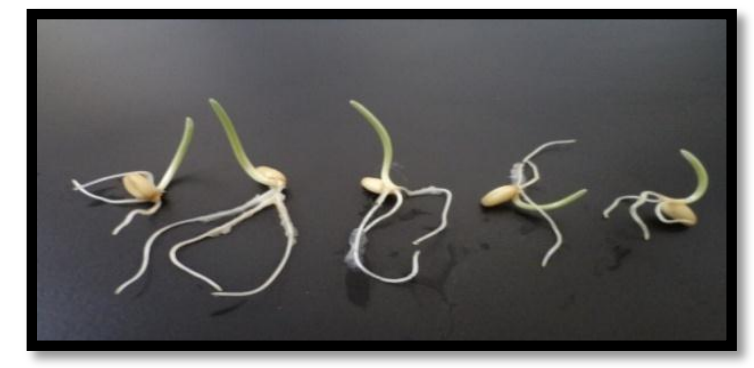

Figure.2 Root and Shoot length of wheat plant

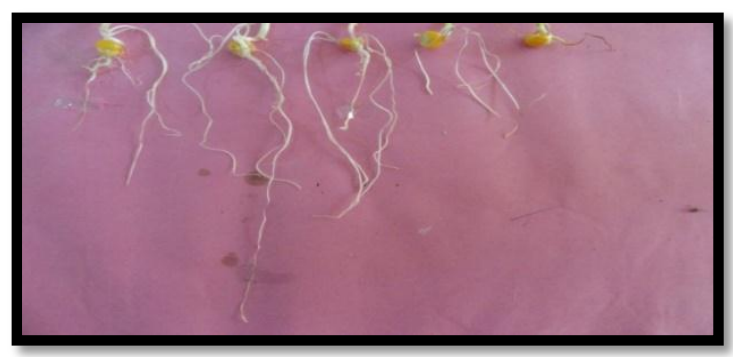

Figure.4 Root length of maize plant.

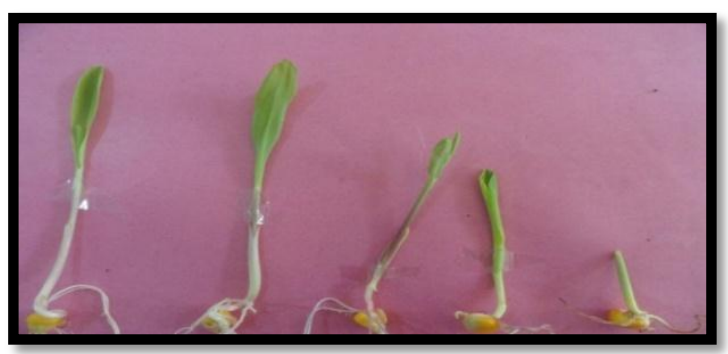

Figure.5 Shoot length of maize plant. 


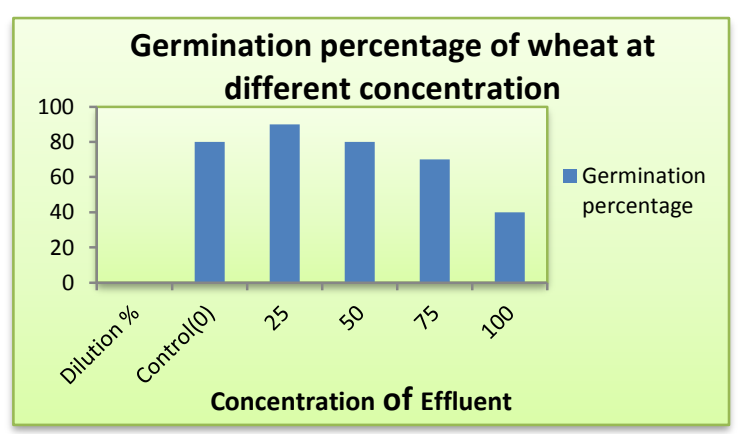

Figure.6 Germination percentage of Wheat at different concentration of effluent

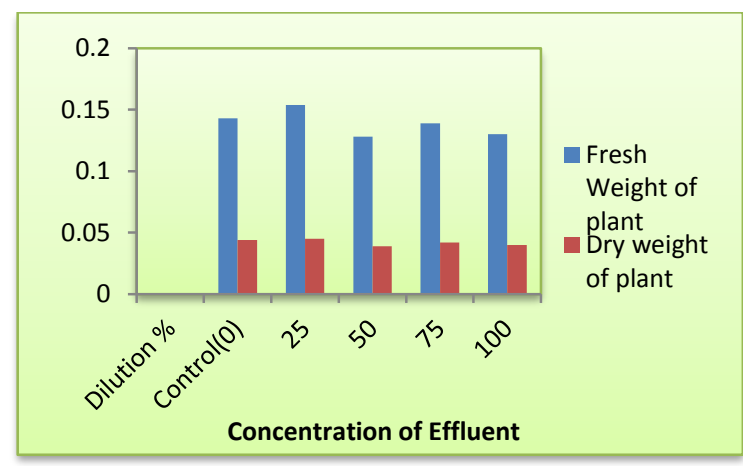

Fig.8 Fresh and dry weight of Wheat plant at different concentration of effluent

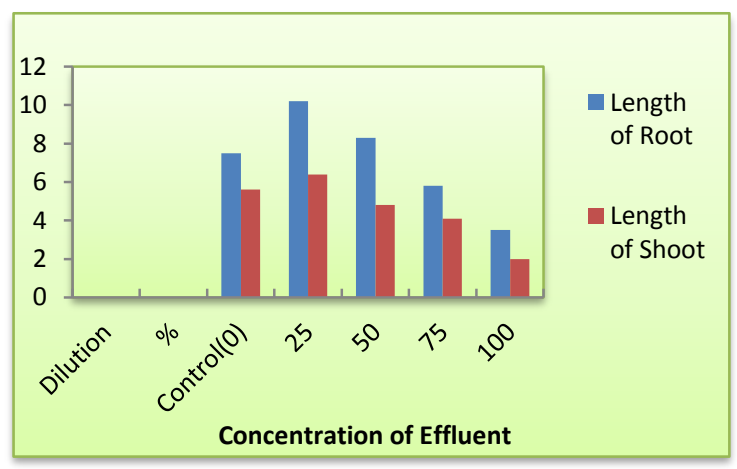

Figure.10 Length of root and shoot of Maize plant at different concentration of effluent

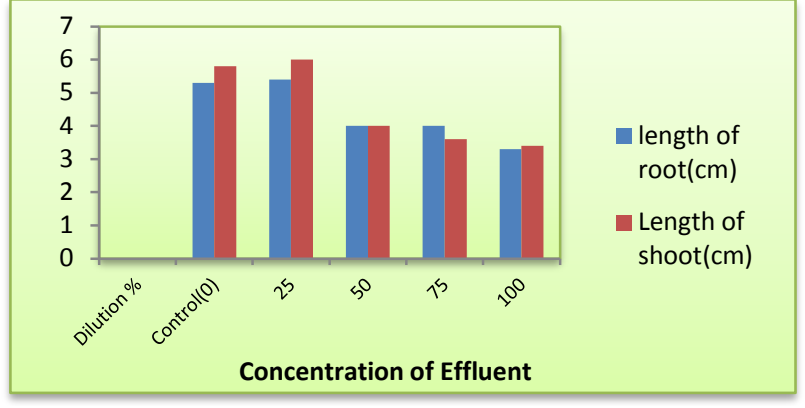

Figure.7 Length of Root and Shoot of Wheat plant at different concentration of effluent

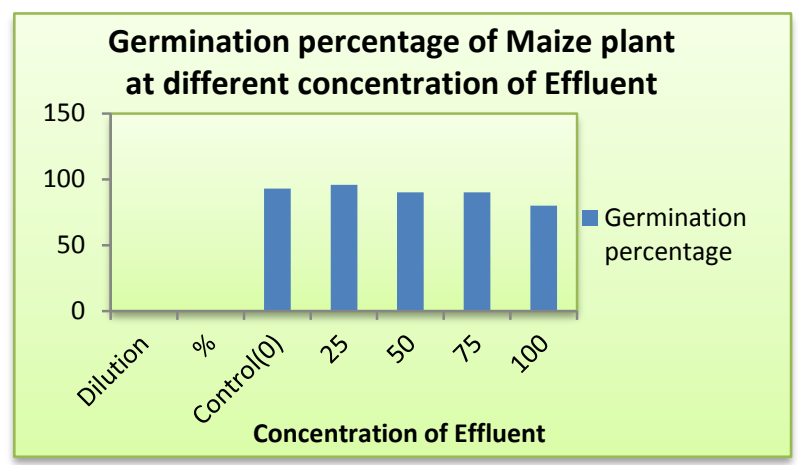

Figure.9 Germination percentage of Maize plant at different concentration of effluent

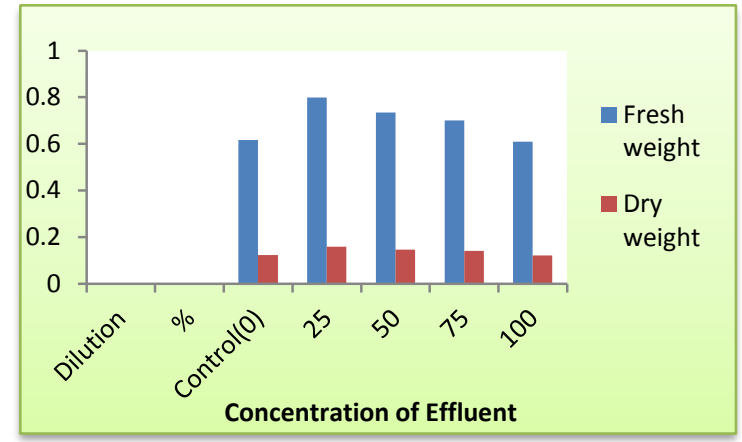

Figure.11 Fresh and dry weight of Maize plant at different concentration of effluent

\section{Conclusion}

The physico-chemical parameters, such as TDS, BOD, COD and Sodium were observed to be higher in sugar mill effluent and it severely affected the plant growth. The results indicates that the sugar industry effluent in low concentration (25\%) has beneficial effect on germination rate and growth parameters such as root length, shoot length, fresh and dry weight of both the plants as compared to control. However adverse effects were indicated in all growth parameters in both plants maize and wheat, when irrigated with various higher effluent concentrations from $50 \%$ to $100 \%$. Thus, effluent with controlled physico-chemical parameters can be utilized for irrigation with promising effects on plants growth and yield. 


\section{References}

[1] APHA, Standard methods for examination of waste water analysis $20^{\text {th }}$ ed.Inc, Washington 1998

[2] AyyasamyPM , Yasodha R, Rajakumar S, Lakshmanaperumalsamy P, Rahman PKSM and Lee S,Impact of sugar Factory Effluent on the Growth and Biochemical Characteristics of Terrestrial and Aquatic Plants. Bull environcontamtoxicol. 81,2008,449-454.

[3] Baskaran L, SundaramoorthyP, Chidambaram ALA and Ganesh KS, Growth and Physiological Activity of Greengram (Vignaradiata L.) Under Effluent Stress. Bot. Res. Int.2, 2009, 107-114.

[4] Baskaran L, Ganesh KS, Chidambaram ALA and SundaramoorthyP,Amelioration of sugarmill Effiuent Polluted Soil and its Effect of Greenngram(Vigna radiate L.) Bot. Res. Int.2, 2009, 131-135.

[5] DhanamS, Effect of dairy effluent on seed germination,seedling growth and biochemical parameter in paddy.Bot.Res.Int.2,2009,6163.

[6] Doke KM, Khan EM, Ropolu J, Shaikh, Physico-chemical analysis of Sugar industry Effluent and its effect on seed germination of Vignaangularis, Vigna cylindrical and Sorghum cernum.Annals of Environmental Science. 5, 2011, 7-11

[7] Ezhilvannan D, Sharavanan PS and VijayaragavanM, Effect of sugar mill effluent on changes of growth and amino acid and protein content of Maize (Zea mays L.) plants. J.of Eco biotech. 3, 2011, 26-29.

[8] Kolhe AS, Ingale SR and Sarode AG. Physico-Chemical analysis Of Sugarmill Effluents.International Research Journal.307-311.

[9] KalaiselviP, Mahimairaja S, Srimathi P and kumar GS,Impact of industrial Effluents in seed Invigouration: A Review.Asian Jr. Of Plant Sciences. 9,2010,249-255.

[10] Kaur A, Vats S, Rekhi S, Bhardwaj A, Goel J, Tanwar RS and Gaur KK, Physico-chemical analysis of the industrial effluents and their impact on the soil microflora.Procedia Environmental Sciences2, 2010, 595-599.

[11] Khatoon T, Hussain K, Majeed A, Nawaz K and Nisar.M F , Morphological Variations in Maize s(Zea mays L.)Under Different Levels of Nacl at germinating stage .World app. Sci. J.8, 2010, 1294-129.

[12] Memon AR, Soomro SA and Ansari AK, Sugar Industry Effluent- Characteristics and Chemical Analysis. J.App.Env.Sci.1, 2006, 152-157.

[13] Medhi UM, Talukdar AK and DekaS, Impact of paper mill effluent on growth and development of certain agricultural crops. J.Environ.Biol. 32, 2011, 185-188.

[14] Nath K, Singh D and Sharma YK, Combinatorial effects of distillery and sugar factory effluents in crop plants. J.ofEnv. Bio.28, 2007, 577-582.

[15] Orhue,Robert E, Osaigbovo, Ulamen A, Vwioko and Emuejevoke D, Growth of maize (Zea mays L.) and changes in some chemical properties of an ultisol amended with brewery. Afri.J.of Biotech. 4, 2005, 973-987.

[16] Osaigbovo, UlamenA, Oehue and Robert E, Influence of pharmaceutical effluent on some soil chemical properties and early growth of Maize (Zea mays L.).African journal of Biotechnology.5, 2006, 1612-1617.

[17] Pandey SK, Tyagi P and Gupta AK (2007). Physico-chemical analysis and effect of distillery effluent on seed germination of wheat (Triticumaestivum), pea (Pisumsativum) and lady's finger (Abelmoschusesculentus). J. of Agri. \& Bio. Sci. 2: 35-40.

[18] Pandey SN, Nautiyal BD and Sharma CP, Pollution Level in distillery effluent and its phytotoxic effect on seed germination and early growth of maize and rice. J. of Envi. Bio.29, 2008, 267-270.

[19] Rath P, Pradhan G, Mishra M K, Effect of sugar factory distillery spent wash (DSW) on the growth pattern of sugarcane (saccharumofficinarum) crop. Journal of Phytology.2 (5), 2010, 33-39.

[20] Shivappa D, PuttaiahET and Kiran BR, Physico-chemical characteristics of sugar mill Effluents-current scenario in BhadravathiTsluk, Karanataka,India. Jr.of Ind. Poll. Control. 23, 2007, 217-221.

[21] SalequzzamanM, Tariqual Islam SM, Tasnuva A, Kashem MA, Mahedi AL and MasudM, Environmental impact of sugar industryA case study on Kushtia sugar mills in Bangladesh. J. Innov.dev.strategy. 2, 2008, 31-35.

[22] Samuel S and Muthukkaruppan SM,Amelioration of sugar Mill Effluent Polluted Soil Using Microbial isolates and it's Response on Paddy. Current Botany.2, 2011, 14-18.

[23] Samuel S and Muthukkaruppan SM, Physico-Chemical Analysis of sugarmill Effluent Contaminated soil and its effect on seed Germination of paddy(Oryza sativa L.). Int.Jr. of Pharma. \& Bio. Archives.2, 2011, 1469-1472.

[24] Saifi MA and Singh HB, Studies on Physico-Chemical Parameters and Concentration of heavy metals in Sugarmill Effluent. Int.J.Chem.Sci. 9, 2011, 929-935.

[25] Siva SK and Suja PR, Effect of Sugarmill effluent on seed germination of Peanut (Arachishypogaea) and Green Gram (Vignaradiata). Int.J.ofPharma. \& chem. Sci. 1, 2012, 804-806.

[26] Siddiqui WA and Waseem M, A Comparative Study of Sugar mill Treated and Untreated Effluent- A case Study.Ori. J. of Chem. 28, 2012, 1899-1904.

[27] Thamizhiniyan P, Sivakumar PV, Lenin M and SivaramanM, Sugar Mill Effluent Toxicity in Crop Plants. J.of Phytology; 1, 2009, 68-74.

[28] VijayaragavanM, SureshkumarJ, NatarajanA, VijayarenganP, SharavananS, and PrabhaharC,Soil irrigation effect of sugar mill effluent on changes of growth and biochemical content of Raphanussativus L. Current botany. 2, 2011, 09-13. 